Article

\title{
Loss of C/EBPS Exacerbates Radiation-Induced Cognitive Decline in Aged Mice due to Impaired Oxidative Stress Response
}

\author{
Sudip Banerjee $\mathbb{D}^{\mathbb{D}}$, Tyler Alexander, Debajyoti Majumdar, Thomas Groves, Frederico Kiffer, \\ Jing Wang, Akshita Gorantla, Antiño R. Allen * and Snehalata A. Pawar *(1) \\ Division of Radiation Health, Department of Pharmaceutical Sciences, College of Pharmacy, University of \\ Arkansas for Medical Sciences, Little Rock, AR 72205, USA; SBanerjee@uams.edu (S.B.); \\ Tyler.alexander@stjude.org (T.A.); DMajumdar@uams.edu (D.M.); tuk52207@temple.edu (T.G.); \\ FCKiffer@uams.edu (F.K.); JWang2@uams.edu (J.W.); akshitagorantla@gmail.com (A.G.) \\ * Correspondence: ARAllen@uams.edu (A.R.A.); SAPawar@uams.edu (S.A.P.); Tel.: +1-501-686-7553 (A.R.A.); \\ +1-501-686-5784 (S.A.P.); Fax: +1-501-686-6057 (A.R.A.); +1-501-686-6057 (S.A.P.)
}

Received: 18 December 2018; Accepted: 11 February 2019; Published: 18 February 2019

\begin{abstract}
Aging is characterized by increased inflammation and deterioration of the cellular stress responses such as the oxidant/antioxidant equilibrium, DNA damage repair fidelity, and telomeric attrition. All these factors contribute to the increased radiation sensitivity in the elderly as shown by epidemiological studies of the Japanese atomic bomb survivors. There is a global increase in the aging population, who may be at increased risk of exposure to ionizing radiation (IR) as part of cancer therapy or accidental exposure. Therefore, it is critical to delineate the factors that exacerbate age-related radiation sensitivity and neurocognitive decline. The transcription factor CCAAT enhancer binding protein delta (C/EBP $\delta$ ) is implicated with regulatory roles in neuroinflammation, learning, and memory, however its role in IR-induced neurocognitive decline and aging is not known. The purpose of this study was to delineate the role of C/EBP $\delta$ in IR-induced neurocognitive decline in aged mice. We report that aged Cebpd $d^{-/-}$mice exposed to acute IR exposure display impairment in short-term memory and spatial memory that correlated with significant alterations in the morphology of neurons in the dentate gyrus (DG) and CA1 apical and basal regions. There were no significant changes in the expression of inflammatory markers. However, the expression of superoxide dismutase 2 (SOD2) and catalase (CAT) were altered post-IR in the hippocampus of aged $\mathrm{Cebpd}^{-/-}$mice. These results suggest that Cebpd may protect from IR-induced neurocognitive dysfunction by suppressing oxidative stress in aged mice.
\end{abstract}

Keywords: Cebpd; C/EBP8; ionizing radiation; hippocampus; behavior; novel object recognition; spatial learning; short-term memory; oxidative stress; reactive oxygen species

\section{Introduction}

There is strong evidence for multifaceted damage to the brain after IR exposure provided by epidemiological studies on the atomic bomb survivors, cancer survivors, and occupational cohorts [1]. The advent of modern medicine has led to a substantial increase in human lifespan and the number of older people among the global population is currently higher and still expanding. The hallmarks of aging are characterized by increased inflammation and deterioration of the cellular stress responses such as the oxidant/antioxidant equilibrium, DNA damage repair fidelity, and telomeric attrition [2]. All these factors contribute to the increased radiation sensitivity in the elderly [2]. Therefore, understanding the mechanistic processes involved in age-related radiation sensitivity is of utmost relevance, particularly in view of the increasing aging population who may be exposed to IR as part 
of cancer therapy or accidental exposure to IR. However, very little is known about the molecular mechanism of increased sensitivity to radiation during aging.

Exposure to IR leads to the expression of pro-inflammatory cytokines and reactive oxygen species (ROS) in the brain areas [3-7]. Loss of verbal memory, spatial memory, attention, and novel problem-solving ability are the hallmarks of radiation-induced cognitive impairment [8-13]. A major role in learning, consolidation, and retrieval of information is done by the hippocampus $[13,14]$. Hippocampus, the main region of the brain where neurogenesis occurs throughout one's lifetime, is highly susceptible to radiation-induced damage [15]. An important player in neurogenesis is the identification of mitochondrial function and, together with observations that mitochondria are targets for ionizing radiation effects, potentially implied mitochondrial dysfunction in radiation-induced deficit of hippocampal neurogenesis-dependent cognition $[4,15,16]$. Regulation of adult neurogenesis depends on the metabolic status of the animal [17]. Previous studies have reported that exposure to total body irradiation (TBI) induces acute alterations in neuronal structure and early cognitive changes $[18,19]$. Data from us and others show that doses of high linear energy transfer radiation from 0.1-1 Gy cause significant, dose-responsive reductions in hippocampal dendritic complexity and spine density, which last for up to nine months post-irradiation [20-23]. Therefore, the purpose of this study was to investigate the early effects of TBI on neurocognitive functions in Cebpd ${ }^{+/+}$and Cebpd $d^{-/-}$ mice. In susceptibility to radiation, age also plays a major role $[2,15,24]$. Although much is known about the late effects of radiation on neurocognitive deficits, very little is known about the molecular markers and morphological changes that occur in the brain in response to acute effects of IR exposure on neurocognitive functions in the context of aging. Understanding these molecular mechanisms of IR's early effects on neurocognitive dysfunction would enable the development of novel interventions to alleviate the adverse effects due to accidental exposure or as part of radiotherapy to the brain.

The transcription factor CCAAT enhancer binding protein delta (C/EBP $)$ is implicated in having a regulatory role in diverse biological functions such as acute-phase response (reaction to inflammation), growth arrest, apoptosis, differentiation, stem cell self-renewal, and tumor suppression [25]. Work by us and others has shown a role for C /EBP $\delta$ in maintaining genomic stability, cell cycle arrest, DNA damage repair, and oxidative stress [26-31]. There are several compelling studies that point to a role of C/EBP in neuroinflammation in diseases such as Alzheimer's, where the ablation of $\mathrm{C} / \mathrm{EBP} \delta$ is shown to confer a protective role [32,33]. We have previously shown a role for C/EBP $\delta$ in radiation response, in promoting post-radiation survival by protection against radiation-induced hematopoietic and intestinal injury, and in modulating basal as well as IR-induced oxidative stress and mitochondrial dysfunction [34,35]. In the present study, we investigated whether the loss of Cebpd exacerbates radiation-induced cognitive deficits due to an impaired ability to detoxify IR-induced ROS and/or inflammation.

\section{Results}

\subsection{Irradiation Impairs Short-Term Memory during Y-Maze Test in Cebpd ${ }^{-1-}$ Mice}

The Y-maze is an established behavioral assay for short-term spatial memory [36]. The amount of time a mouse spends exploring a novel arm relative to the familiar arm in the testing phase is indicative of its ability to retain the spatial memory encoded during familiarization. We observed that $\mathrm{Cebpd}^{+/+}$-sham, Cebpd $d^{+/+}$-IR, and Cebpd $d^{-/-}$-sham groups displayed significant differences in exploration between the maze arms during the testing phase $\left(C e b p d^{+/+}\right.$-sham: $\mathrm{F}_{(2,12)}=8.16, p<0.01$; Cebpd $d^{+/+}$-IR: $\mathrm{F}_{(2,18)}=16.21 ; p<0.001 ; C_{\text {Cebpd }}{ }^{-/-}$-sham: $\left.\mathrm{F}_{(2,12)}=6.56 ; p<0.05\right)$. Post-hoc tests indicate that $\mathrm{Cebpd}^{+/+}$-sham animals spent significantly more time exploring the novel than the familiar $(p<0.05)$ or start $\left(p<0.01\right.$; Figure 1A) arms. Similarly, the Cebp $d^{+/+}$-IR treatment group also spent significantly more time exploring the novel than the familiar $(p<0.001)$ or start $(p<0.001$; Figure 1B) arms. Next, the Cebpd $d^{-/-}$-sham group was also successful in exploring the novel arm for longer periods of time than the familiar or start arms ( $p<0.05$; Figure 1C). However, the Cebpd $d^{-/-}$-IR animals 
displayed impaired short-term memory $\left(\mathrm{F}_{(2,12)}=1.25 ; p=0.32\right.$; Figure 1D) spending equal amounts of time exploring the novel and start arms.
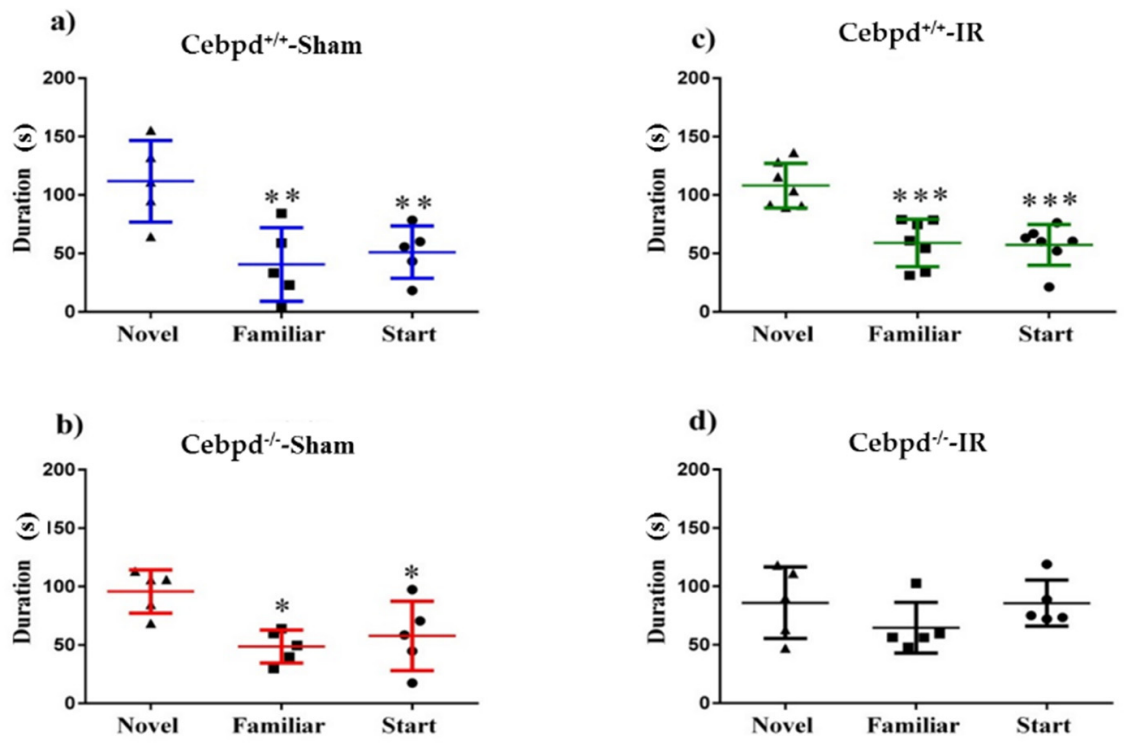

Figure 1. Short-term memory analyzed by Y-maze test in sham and irradiated aged Cebpd ${ }^{+/+}$and Cebpd $d^{-/-}$mice. (A-C) Cebpd $d^{+/+}$-sham, Cebpd $d^{+/+}$-IR, and Cebpd $d^{-/-}$-sham mice were able to successfully distinguish the novel arm, by spending significantly more time exploring it. (D) Cebpd ${ }^{-/-}$-IR mice were not able to distinguish between the three Y-maze arms, and spent an approximately equal time exploring all arms failing to recognize the novel environment when exposed to it $4 \mathrm{~h}$ later. $\mathrm{N}=5 / 7$ mice/treatment, Average $\pm \mathrm{SEM}^{*} p<0.05,{ }^{* *} p<0.01,{ }^{* * *} p<0.001$.

\subsection{Irradiation Impairs Spatial Memory in Aged Cebpd ${ }^{-/-}$Mice}

We used the novel object recognition (NOR) task to assess non-spatial declarative memory [37]. Rodents naturally orient their head toward novel stimuli, behavior that provides a simple and effective method for quantifying visual recognition [38]. Visuospatial orientation toward an object will attenuate with arena exposure time (habituation), and contrasting exploration of a novel versus a familiar object provides an index of object recognition and discrimination. Habituation learning occurs when animals' response to a stimulus lowers with increased exposure. Locomotor activity was tracked on the two empty arena habituation days, and the difference between total distances moved between open arena days 1 and 2 serve as a metric for habituation learning. There was no significant difference in distance moved day $1\left(\mathrm{~F}_{(3,18)}=0.73 ; p=0.55\right)$ nor day $2\left(\mathrm{~F}_{(3,18)}=1.79 ; p=0.18\right)$. During familiarization (day 3 ), mice were placed in the open field box with two identical objects. On day 4 , one of the objects (henceforth "familiar") was replaced with a novel object. Statistical analysis of total object exploration in test sessions revealed that Cebpd ${ }^{+/+}$-sham $\left(t=5.33, p=0.007\right.$; Figure 2A), Cebpd $d^{+/+}$-IR $(t=3.40, p=0.005$; Figure 2B) and Cebpd $d^{-/-}$-sham $(t=2.85, p=0.02$; Figure 2C) mice showed novel object recognition and visited the novel object significantly more than the familiar object. However, radiation exposure significantly impaired Cebpd ${ }^{-1-}$ mice (Figure 2D) as they did not show any preferences for the novel object. Discrimination ratios provide a basis for interpreting animals' ability to remember or forget a novel arm or object. A positive ratio can be interpreted as animals successfully discriminating between two objects, and a negative ratio implies "forgetting" an object [39]. Radiation resulted in a negative discrimination ratio for Cebpd $d^{-/-}-\mathrm{IR}$ mice $\left(\mathrm{F}_{(3,17)}=4.42 ; p<0.05\right.$; Figure S1, Supplementary Materials). 

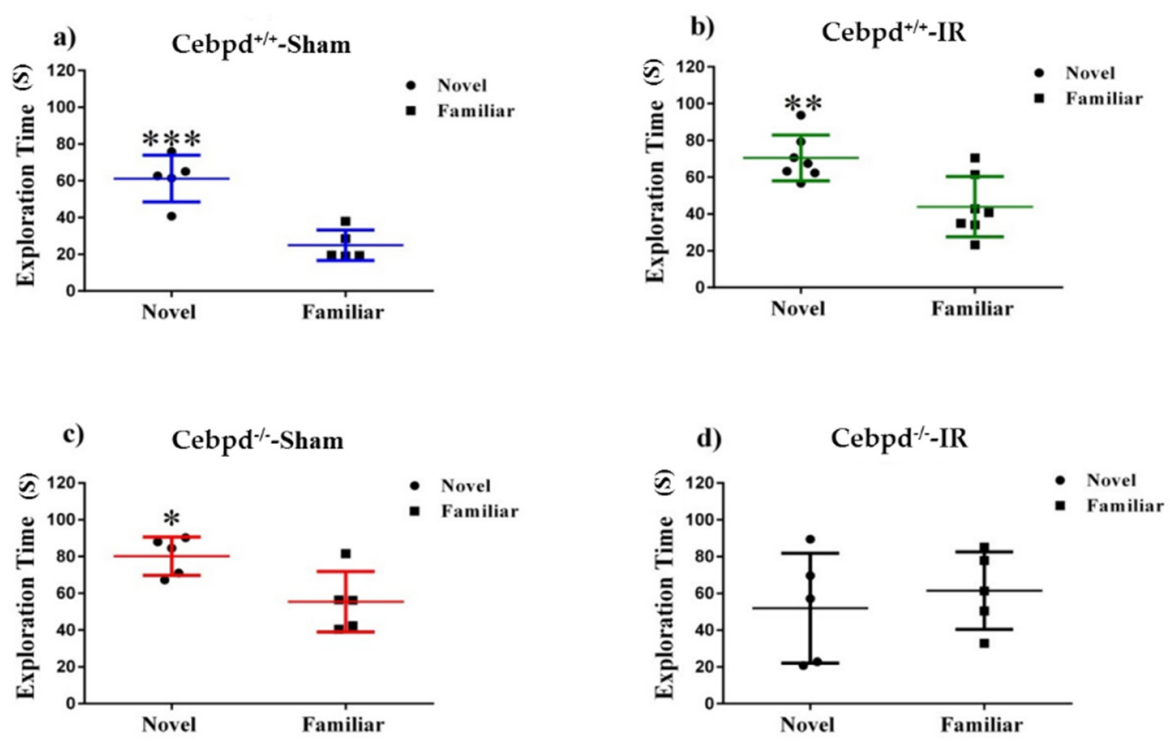

Figure 2. NOR of sham-irradiated and irradiated aged Cebpd $d^{+/+}$and Cebpd $d^{-/-}$mice. (A) Cebpd $^{+/+}$-sham, (B) Cebpd $d^{+/+}$-IR, and (C) Cebpd $d^{-/-}$-sham irradiated mice showed novel object recognition and spent more time exploring the novel than the familiar object. However, Cebpd ${ }^{-/-}$-IR (D) mice did not show any preference for the novel object. $\mathrm{N}=5 / 7$ mice/treatment. Average $\pm \mathrm{SEM}$; * $p<0.05,{ }^{* *} p<0.01,{ }^{* * *} p<0.001$.

2.2.1. Dendritic Morphology of Dentate Gyrus Granule Neurons is Significantly Altered in Irradiated $\mathrm{Cebpd}^{-1-}$ Mice

For morphological quantification of hippocampal neurons, we measured length and branching of the granule cells in the dentate gyrus (DG) and pyramidal neurons in the CA1 region from 5 Cebpd $d^{-/-}$ and $7 \mathrm{Cebpd}^{+/+}$mice. First, we examined dendritic complexity in the DG between treatment groups. An ANOVA found differences in dendritic complexity $\left(\mathrm{F}_{(3,12)}=9.81 ; p<0.001\right)$. Multiple comparisons show a marked decrease in complexity between Cebpd ${ }^{-/-}$sham compared to Cebpd $d^{-/-}$-IR $(p<0.01$; see Table 1). There were no significant differences between Cebpd ${ }^{+/+}$-sham compared to Cebpd ${ }^{-/-}$-sham nor between $\mathrm{Cebpd}^{+/+}$-sham compared to Cebpd $d^{+/+}$-IR. The variables that define dendritic complexity changed due to irradiation to similar extents as compared to sham. We observed decreases in dendritic length $\left(\mathrm{F}_{(3,12)}=11.78 ; p<0.001\right)$ and total branch points $\left(\mathrm{F}_{(3,12)}=19.88 ; p<0.0001\right.$; see Table 1$)$.

Table 1. Analysis of dendritic morphology of dentate gyrus (DG) granule neurons in aged Cebpd $d^{+/+}$ and Cebpd $d^{-/-}$mice. ${ }^{* * *}$ Bold figures represent significant compared to Cebpd ${ }^{-/}-$IR.

\begin{tabular}{ccccc}
\hline Cell Type and Measurements & $\begin{array}{c}\text { Cebpd }^{+/+} \text {-Sham } \\
(\mathbf{m e a n} \pm \text { SEM) }\end{array}$ & $\begin{array}{c}\text { Cebpd } \\
\text { (mean } \pm \text { SEM) }\end{array}$ & $\begin{array}{c}\text { Cebpd }^{+/+} \text {-IR } \\
\text { (mean } \pm \text { SEM) }\end{array}$ & $\begin{array}{c}\text { Cebpd }^{-/-} \text {-IR } \\
(\text { mean } \pm \text { SEM) }\end{array}$ \\
\hline Total Dendritic Length & $1224 \pm 77.77$ & $1313 \pm 86.06$ & $987.4 \pm 144.5$ & $587.7 \pm 36.45$ \\
\hline $\begin{array}{c}\text { Total Number of Branch } \\
\text { Points }\end{array}$ & $8.92 \pm 0.57$ & $8.08 \pm 0.57$ & $5.8 \pm 0.72$ & $3.8 \pm 0.21$ \\
\hline Complexity & $30796 \pm 6401$ & $38947 \pm 3424$ & $15985 \pm 5436$ & $7050 \pm 1350$ \\
\hline
\end{tabular}

The effect of irradiation was found to be associated with a different distribution of dendritic branches over the entire tree in the DG, as determined by ANOVA. We detected significant interactions between treatment and dendritic length $\left(\mathrm{F}_{(89,348)}=12.83 ; p<0.0001\right)$. We also found significant main effects of Sholl dendritic length $\left(\mathrm{F}_{(29,348)}=110.4 ; p<0.0001\right)$ and main effect of treatment $\left(\mathrm{F}_{(3,12)}=11.78\right.$; $p<0.001)$. We next performed post-hoc analyses, which revealed a decrease in the dendritic length significantly evident when Cebpd $d^{-/-}$-sham were compared to Cebpd ${ }^{-/-}$-IR. Analysis revealed a significant decrease in dendritic length at 90-190 $\mu \mathrm{m}$ (Holm-Sidak's multiple comparisons: $90 \mu \mathrm{m}$, 
$p<0.05 ; 100 \mu \mathrm{m}, p<0.001 ; 110-190 \mu \mathrm{m}, p<0.0001$; Figure 3). We found no significant interactions between genotype and dendritic Sholl length $\left(\mathrm{F}_{(29,174)}=0.81 ; p=0.74\right.$; Figure 3) when Cebpd ${ }^{+/+}$-sham were compared to Cebpd $d^{-/-}$-sham. Nor was there a significant interaction between treatment and dendritic Sholl $\left(\mathrm{F}_{(29,174)}=0.92 ; p=0.57\right.$; Figure 3) when Cebpd $d^{+/+}$-sham were compared to Cebpd $d^{+/+}$-IR.
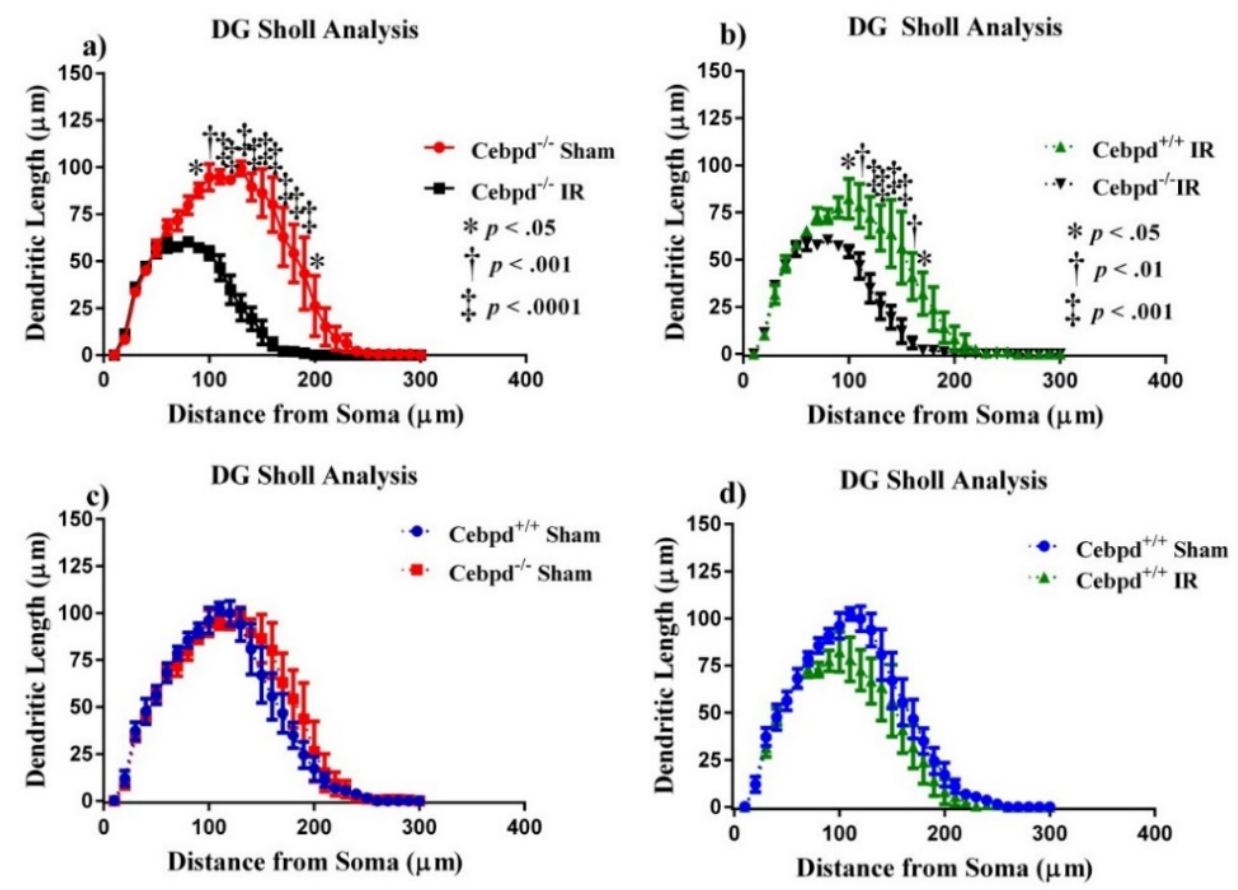

Figure 3. Sholl analyses of neurons in the dentate gyrus. (A) Dendritic length, measured by Sholl analysis, radiation greatly decreased length at 90-100 $\mu \mathrm{m}$ from the soma when Cebpd ${ }^{-/-}$-sham were compared to Cebpd $d^{-/-}$-IR. (B) Treatment decreased length at 100-170 $\mu \mathrm{m}$ from the soma when $\mathrm{Cebpd}^{+/+}$-IR were compared to Cebpd $d^{-/-}$-IR. There were no significant differences observed when

(C) $\mathrm{Cebpd}^{+/+}$-sham were compared to Cebpd ${ }^{-/-}$-sham or (D) Cebpd $d^{+/+}$-sham were compared to $\mathrm{Cebpd}^{+/+}$-IR. Average $\pm \operatorname{SEM}(n=5) ;^{*} p<0.05,{ }^{\dagger} p<0.01$. ${ }^{\ddagger} p<0.001$.

2.2.2. Dendritic Morphology of CA1 Apical Neurons is Significantly Altered in Irradiated Cebpd $^{-/-}$Mice

We next examined dendritic complexity in the CA1 neurons between treatment groups. An ANOVA found differences in dendritic complexity $\left(\mathrm{F}_{(3,12)}=6.50 ; p<0.01\right)$. Multiple comparisons show a marked decrease in complexity between Cebpd $d^{+/+}$-sham compared to Cebpd $d^{+/+}-\mathrm{IR}(p<0.05)$. We also observed decreases in dendritic length $\left(\mathrm{F}_{(3,12)}=9.06 ; p<0.01\right)$ and total branch points $\left(\mathrm{F}_{(3,12)}\right.$ $=7.80 ; p<0.01$; see Table 2 ) in both dosage groups.

We report significant interactions between treatment groups and dendritic Sholl length in the CA1 apical neurons. Similar to what was seen in the DG, we detected significant interactions between treatment and dendritic length $\left(\mathrm{F}_{(87,348)}=2.54 ; p<0.0001\right)$. We also found significant main effects of Sholl dendritic length $\left(\mathrm{F}_{(29,348)}=127.1 ; p<0.0001\right)$ and main effect of treatment $\left(\mathrm{F}_{(3,12)}=11.78\right.$; $p<0.001)$. We next performed post-hoc analyses, which revealed a decrease in the dendritic length significantly evident when Cebpd $d^{-/-}$-sham were compared to Cebpd $d^{-/-}$-IR. Analysis revealed a significant decrease in dendritic length at 80-160 $\mu \mathrm{m}$ (Holm-Sidak's multiple comparisons: 80-150 $\mu \mathrm{m}$, $p<0.0001 ; 160 \mu \mathrm{m}, p<0.001$; Figure 4). We found no significant interactions between genotype and dendritic Sholl length $\left(\mathrm{F}_{(29,174)}=0.41 ; p=0.99\right.$; Figure 4) when Cebpd $d^{+/+}$-sham were compared to $\mathrm{Cebpd}^{-/-}$-sham. Nor was there a significant interaction between treatment and dendritic Sholl (F $(29,174)=1.10 ; p=0.34 ;$ Figure 4$)$ when Cebpd $d^{+/+}$-sham were compared to Cebpd $d^{+/+}$-IR. 
Table 2. Analysis of CA1 apical and basal neurons in aged Cebpd $d^{+/+}$and Cebpd $d^{-/-}$mice. ${ }^{* * *}$ Bold figures represent significant compared to $\mathrm{Cebpd}^{-/-}$-IR.

\begin{tabular}{|c|c|c|c|c|}
\hline $\begin{array}{l}\text { Cell Type and } \\
\text { Measurements }\end{array}$ & $\begin{array}{l}\text { Cebpd } d^{+/+} \text {-Sham } \\
(\text { mean } \pm \text { SEM) }\end{array}$ & $\begin{array}{c}\text { Cebpd } d^{-1-} \text {-Sham } \\
(\text { mean } \pm \text { SEM) }\end{array}$ & $\begin{array}{c}\text { Cebpd } d^{+/+}-\mathrm{IR} \\
(\text { mean } \pm \text { SEM) }\end{array}$ & $\begin{array}{c}\text { Cebpd } d^{-/-}-\mathrm{IR} \\
(\text { mean } \pm \text { SEM) }\end{array}$ \\
\hline \multicolumn{5}{|c|}{ CA1 Apical } \\
\hline Total Dendritic Length & $839.8 \pm 82.52$ & $677.6 \pm 74.02$ & $519.1 \pm 43.86$ & $414.6 \pm 32.46$ \\
\hline $\begin{array}{l}\text { Total Number of } \\
\text { Branch Points }\end{array}$ & $8.00 \pm 0.96$ & $7.13 \pm 0.58$ & $5.3 \pm 0.39$ & $4.05 \pm 0.45$ \\
\hline Complexity & $43356 \pm 9937$ & $29426 \pm 6042$ & $17154 \pm 1491$ & $8699 \pm 1649$ \\
\hline \multicolumn{5}{|c|}{ CA1 Basal Measurements } \\
\hline Total Dendritic Length & $1301 \pm 173.34$ & $823.01+52.91$ & $788.8 \pm 22.93$ & $472.6 \pm 28.61$ \\
\hline $\begin{array}{l}\text { Total Number of } \\
\text { Branch Points }\end{array}$ & $9.90 \pm 1.35$ & $7.00+0.64$ & $6.95 \pm 0.49$ & $3.85 \pm 0.52$ \\
\hline Complexity & $20722 \pm 5219$ & $8366+1556$ & $9275+1671$ & $3749 \pm 540.5$ \\
\hline
\end{tabular}
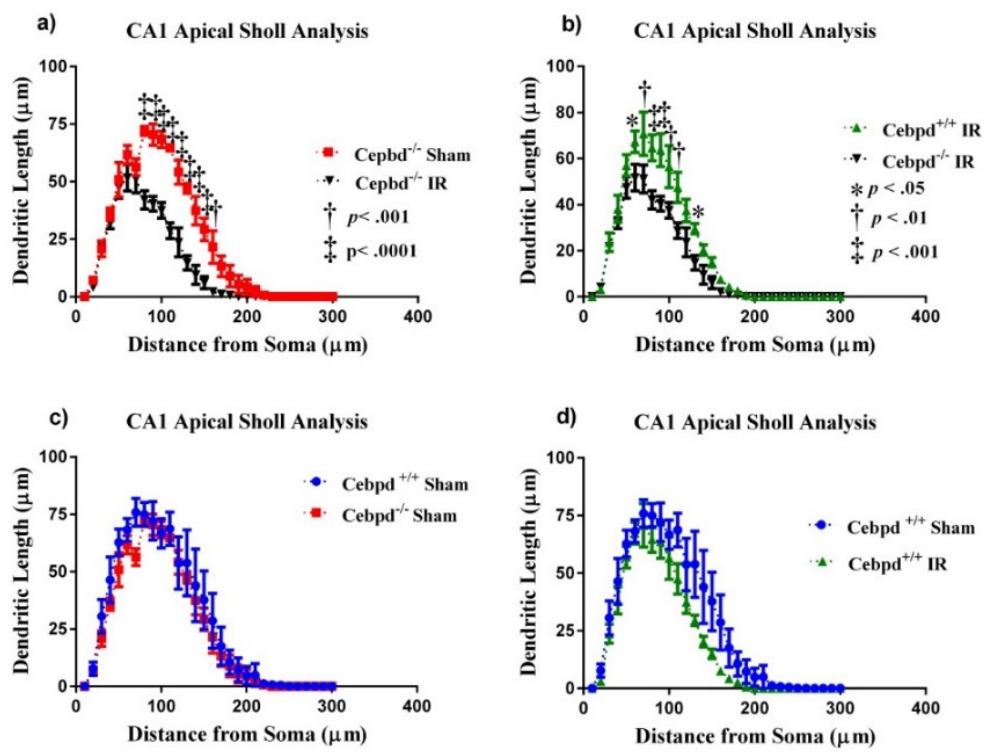

Figure 4. Sholl analyses of neurons in the CA1 apical. (A) Dendritic length, measured by Sholl analysis radiation decreased length at $80-160 \mu \mathrm{m}$ from the soma when Cebpd ${ }^{-/-}$-sham were compared to Cebpd ${ }^{-/-}$-IR. (B) Treatment greatly decreased length at 80-160 $\mu \mathrm{m}$ from the soma when Cebpd $d^{+/+}$IR were compared to Cebpd $d^{-/-}$-IR. There were no significant differences observed when (C) $\mathrm{Cebpd}^{+/+}$-sham were compared to Cebpd $d^{-/-}$-sham or (D) Cebpd $d^{+/+}$-sham were compared to Cebpd ${ }^{+/+}$-IR. Average $\pm \operatorname{SEM}(n=5) * p<0.05,{ }^{\dagger} p<0.01 .{ }^{\ddagger} p<0.001$.

2.2.3. Dendritic Morphology of CA1 Basal Neurons is Significantly Altered in Irradiated Cebpd $^{-/-}$Mice

In the CA1 basal pyramidal dendrites, the ANOVA also found differences in dendritic complexity $\left(\mathrm{F}_{(3,12)}=6.35 ; p<0.01\right)$. Multiple comparisons show a significant decrease in complexity when Cebpd $^{+/+}$-IR were compared to Cebpd $d^{-/-}$-IR $(p<0.05)$. We also observed decreases in dendritic length $\left(\mathrm{F}_{(3,12)}=13.64 ; p<0.001\right)$ and total branch points $\left(\mathrm{F}_{(3,12)}=8.80 ; p<0.01\right.$; see Table 2$)$. We detected significant interactions between treatment and dendritic length $\left(\mathrm{F}_{(87,348)}=8.06 ; p<0.0001\right)$. We also found significant main effects of Sholl dendritic length $\left(\mathrm{F}_{(29,348)}=178.5 ; p<0.0001\right)$ and main effect of treatment $\left(\mathrm{F}_{(3,12)}=12.31 ; p<0.001\right)$. Post-hoc analyses revealed a significant decrease in the dendritic length when Cebpd $d^{+/+}$-sham were compared to Cebpd $d^{+/+}$IR at 90-140 $\mu \mathrm{m}$ from the soma (Holm-Sidak's multiple comparison: $90 \mu \mathrm{m}, p<0.01 ; 100-130 \mu \mathrm{m}, p<0.001 ; 140 \mu \mathrm{m}, p<0.01$ Figure 5). 
When Cebpd $d^{+/+}$-sham were compared to Cebpd ${ }^{-/-}$-sham, analysis revealed a significant decrease in dendritic length at 90-130 $\mu \mathrm{m}$ (Holm-Sidak's multiple comparisons: $90 \mu \mathrm{m}, p<0.01 ; 100-120 \mu \mathrm{m}$, $p<0.0001 ; 130-140 \mu \mathrm{m}, p<0.05$; Figure 5). When Cebpd $d^{-/-}$-sham were compared to Cebpd $d^{-/-}$-IR, analysis revealed a significant decrease in dendritic length at 50-110 $\mu \mathrm{m}$ (Holm-Sidak's multiple comparisons: $50-100 \mu \mathrm{m}, p<0.0001 ; 110 \mu \mathrm{m}, p<0.001$; Figure 5).
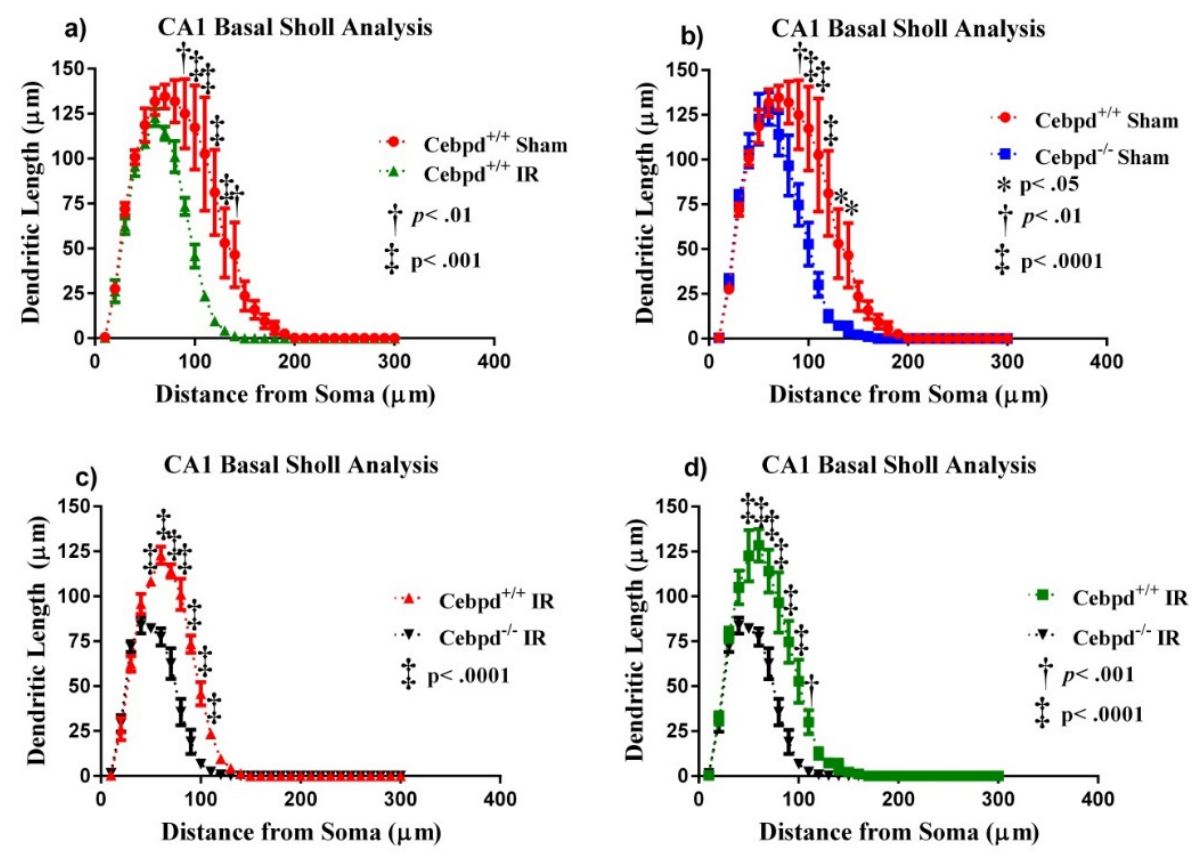

Figure 5. Sholl analyses of neurons in the CA1 basal. (A) Dendritic length, measured by Sholl analysis radiation decreased length at 90-140 $\mu \mathrm{m}$ from the soma when Cebpd $d^{+/+}$-sham were compared to Cebpd $d^{++}$-IR. (B) There was a decrease in length at 90-140 $\mu \mathrm{m}$ from the soma when Cebpd $d^{+/+}$-sham were compared to Cebpd $d^{-/-}$-sham. (C) Radiation decreased length at 50-110 $\mu \mathrm{m}$ from the soma when $\mathrm{Cebpd}^{+/+}$-IR were compared to Cebpd $d^{-/-}$-IR. (D) Treatment greatly decreased length at 50-110 $\mu \mathrm{m}$ from the soma when Cebpd $d^{-/-}$-sham were compared to Cebpd $d^{-/-}$-IR. Average $\pm \operatorname{SEM}(n=5)$.

2.3. Irradiated Cebpd ${ }^{-1}$ Mice Show Impaired Expression of Antioxidant Response Proteins, but no Change in the Expression of Inflammatory Markers in the Hippocampus

Exposure to IR is known to induce the expression of toll-like receptor 4 (TLR4) and pro-inflammatory cytokines which promote the increased recruitment of immune cells to clear the damaged tissue and/or dying cells. The activation of TLR4 is primarily in the microglia, so we also examined the expression of CD68, a marker of activated glia in the hippocampal extracts. We did not observe a significant difference in the expression of TLR4 nor CD68, which suggests that Cebpd-deficiency in aged mice did not further exacerbate IR-induced inflammation compared to unirradiated $\mathrm{Cebpd}^{+/+}$mice (Figure 6).

Exposure to IR induces increased oxidative stress and damage to cellular constituents and leads to cell death and damage to the tissues. The hippocampus, which is the center for neurogenesis, is sensitive to IR-induced oxidative stress which can be counteracted by the antioxidant response proteins such as nuclear factor (erythroid-derived 2)-like 2 (NRF2), superoxide dismutase 2 (SOD2), catalase (CAT), and gamma-glutamyl cysteine ligase subunit $\mathrm{m}$ ( $\gamma$-GCSm). There was no significant difference between the genotypes in sham or irradiated groups in the expression of antioxidant response proteins such as NRF2 or $\gamma$-GCSm which is involved in the synthesis of the cellular antioxidant glutathione. The expression of SOD2 was significantly upregulated in Cebpd $d^{-/-}$-sham mice compared to Cebpd ${ }^{+/+}$-sham mice. Exposure to IR led to downregulation of the overall expression of SOD2 in $\mathrm{Cebpd}^{+/+}$mice, however Cebpd $d^{-/-}$mice still showed significantly higher expression (Figure 7). We also found that the post-IR hippocampal expression of CAT was significantly decreased in Cebpd ${ }^{-/-}$mice 
compared to $\mathrm{Cebpd}^{+/+}$mice (Figure 7). These results point to impairment in the oxidative stress response proteins and is suggestive of increased oxidative damage in the hippocampus which may play a role in neurocognitive deficits observed in Cebpd $d^{-/-}$mice.
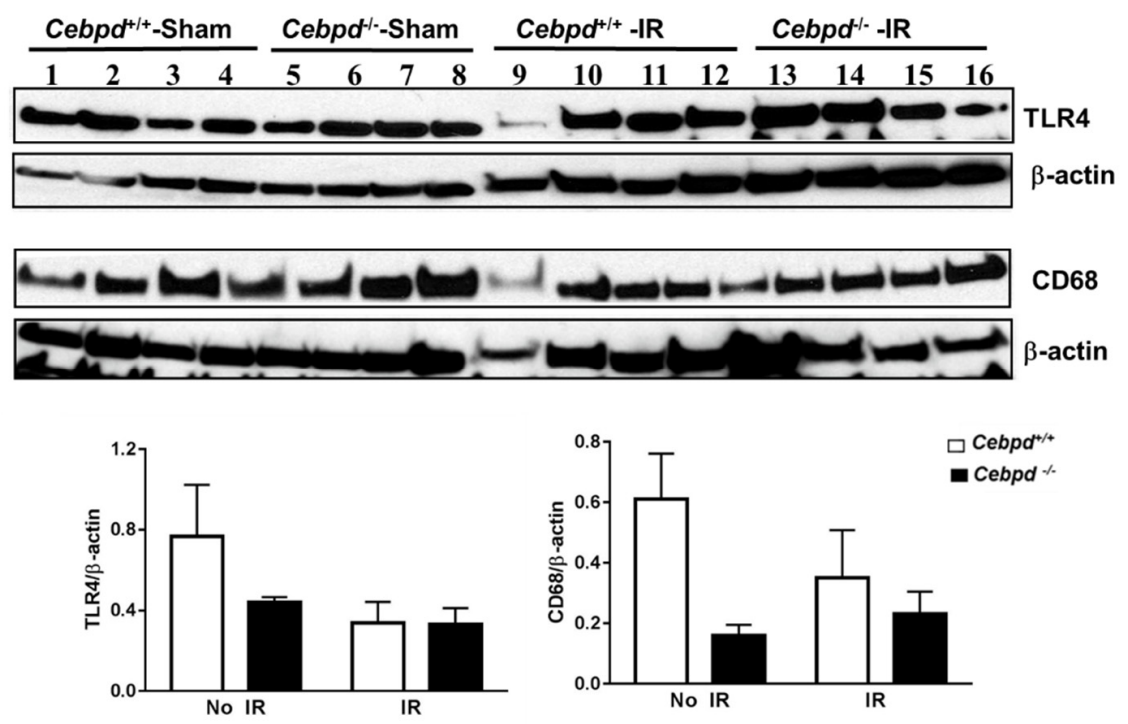

Figure 6. Expression of markers of inflammation and activated microglia in sham and irradiated $\mathrm{Cebpd}^{+/+}$and Cebpd $d^{-/-}$hippocampal extracts of aged mice. Immunoblotting of TLR4 and CD68 normalized to $\beta$-actin used as a loading control, $n=4$ mice per genotype per treatment.
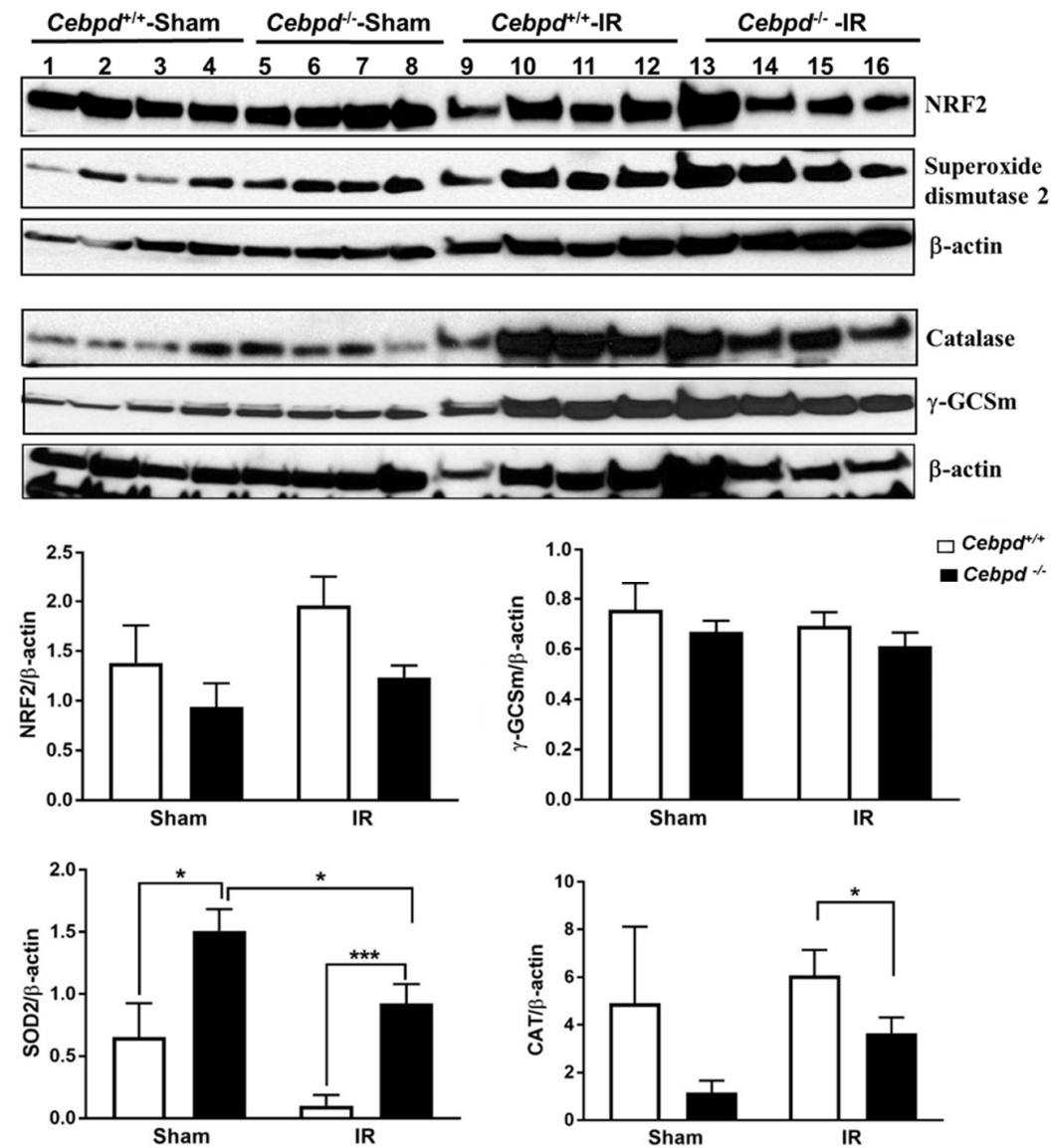

Figure 7. Expression of antioxidant response proteins in hippocampal extracts of sham and irradiated $\mathrm{Cebpd}^{+/+}$and Cebpd $d^{-/-}$mice. Immunoblotting of hippocampal extracts probed for NRF2, SOD2, CAT, $\gamma$-GCSm and $\beta$-actin, $n=4$ mice per genotype per treatment. ${ }^{*} p<0.05 ;{ }^{* *} p<0.001$. 


\section{Discussion and Conclusions}

Most of the clinical observations on radiation-induced neurocognitive impairments are based on the uncontrolled accidental exposure to radiation or the controlled cranial radiotherapy in cancer patients. Radiation exposure of the brain disrupts neurotransmission and elicits varying degrees of cognitive dysfunction [9-11]. While severe macroscopic tissue destruction and functional central nervous system (CNS) injury generally occur only after high radiation doses, lower doses do elicit moderate, acute changes [10]. Exposure to radiation gives rise to oxidative stress and neuroinflammation neurochemical mechanism detrimental to proper functionality of the CNS [40]. In young adult mice, significant reductions in proliferating and immature neurons are seen shortly after irradiation (i.e., $48 \mathrm{~h}$ ) after irradiation [41]. In juvenile mice (age p21) $48 \mathrm{~h}$ after irradiation, the number of immature neurons is reduced $12 \%$ after 2 Gy to $75 \%$ after 10 Gy [42].

$\mathrm{C} / \mathrm{EBP} \delta$ expression is low to undetectable in most cell types and tissues. Activation of C/EBP $\delta$ has been observed in age-associated inflammatory diseases such as Alzhiemer's disease and Parkinson's disease [32,33]. Sterneck et al. previously demonstrated that Cebpd is expressed in distinct neuronal populations, including the granule neurons of the dentate gyrus and the pyramidal neurons of the hippocampus, and that young Cebpd ${ }^{-/-}$mice display an enhancement in contextual fear conditioning but not spatial learning in the Morris task [43]. Microarray analysis of genes expressed in the brains of young versus old mice revealed that the expression of Cebpd is not influenced by age [44].

The Y-maze is a simple 2-trial recognition test for measuring spatial recognition memory in animal experiments. The Y-maze test is based on the instinctive curiosity of rodents to explore novel areas without negative or positive reinforcements to the animals [45]. In the present study, one of the interesting findings was that aged Cebpd $d^{++}$mice that received whole body radiation were not affected cognitively. However, Cebpd $d^{-/-}$-IR animals' lack of curiosity about the novel arm, implying the inability to remember the start or the familiar arms, suggests deficits in the hippocampus-dependent process of short-term recall [46].

Recognition, a subtype of declarative memory, is composed of familiarity and recollection, which are processes dependent upon the hippocampus [38]. Recent findings are categorizing organized electrical activity in response to NOR within the hippocampus $[23,38,47]$. The dorsal hippocampus in particular is implicated in novel-object signaling. Within the dorsal hippocampus, the CA1 is paramount for object-novelty processing, as it is the main hippocampal output of the tri-synaptic pathway and broadcasts environmental novelty $[48,49]$. Our data showed that NOR was impaired significantly in Cebpd $d^{-/-}$-IR mice compared to Cebpd $d^{-/-}$-sham and Cebpd $d^{+/+}$-sham and Cebpd $d^{+/+}$-IR cohorts. However, since Cebpd $d^{-/-}$-IR mice explore objects equally during familiarization and exhibit no signs of neophobia, deficits in NOR are likely due to impaired learning and/or memory rather than reduced curiosity.

Dendritic branching alterations and spine morphology can disrupt synapse formation and/or stability, which ultimately can lead to neurological and cognitive disorders, such as autism spectrum disorders, Alzheimer's disease, schizophrenia, anxiety, and depression [50]. Loss of dendritic arborization complexity would prohibit information processing and learning and memory formation that can manifest as cognitive dysfunction [51,52]. Neurons were once thought to be radioresistant cells because they do not divide, but we now know that they respond negatively to radiation. Our data showed significantly decreased dendritic length in the DG and CA1 regions of the hippocampus of irradiated Cebpd $d^{-/-}$mice. In the DG, Sholl analysis of Cebpd $d^{+/+}$-sham mice compared with $\mathrm{Cebpd}^{+/+}$-IR mice revealed significant reductions in dendritic length at 80-190 $\mu \mathrm{m}$ from the soma, with similar reductions at 90-190 $\mu \mathrm{m}$ in Cebpd ${ }^{-/-}$-sham mice when compared with Cebpd ${ }^{-/-}$-IR mice. Dendritic morphology has been implicated in the health of neurons [53]; these data suggest that $\mathrm{C} / \mathrm{EBP} \delta$-deficiency enhanced neuronal damage after exposure to radiation. Our findings of changes in dendritic morphology are aligned with findings in the literature showing abnormal morphology and decreased complexity are associated with impaired learning and memory on behavioral testing [54]. 
It is known that cumulative oxidative stress and inflammation play a contributory role in the process of aging and are also associated with radiation injury [2,55-57]. In the present study, we did not find any significant changes in the expression of markers of inflammation such as TLR4 or in the expression levels of the marker for activated microglia, CD68. It is known that aging is also associated with chronic inflammation partly mediated by increased levels of damage-associated molecular patterns, which activate pattern recognition receptors of the innate immune system such as TLR4 [58]. It is perhaps possible that due to the baseline inflammation present in the aged mice, radiation does not further upregulate the expression of TLR4. Alternatively, it may be possible that the inflammatory peak is an early effect post-IR exposure and perhaps TLR4 may be upregulated at early time points in Cebpd $d^{-/-}$mice, as observed in other tissues such as the intestine [59].

However, we found significant alterations in the post-irradiation expression of the antioxidant proteins, SOD2, and CAT between aged Cebpd $d^{-/-}$and $\mathrm{Cebpd}^{+/+}$mice It is known that the generation of ROS is considered the main cause of radiation-induced tissue injuries, and elevated levels of oxidative stress persist long after the initial irradiation [60]. We found significant upregulation of SOD2 in sham as well as irradiated Cebpd ${ }^{-/-}$mice. Interestingly, a study with proton irradiation reported that SOD2-deficient mice were protected from radiation-induced neurocognitive deficits compared to SOD2-wild type mice [61]. The hydrogen peroxide produced by SOD2 is further detoxified by the enzyme CAT which was found to be significantly downregulated in irradiated Cebpd $d^{-/-}$ mice. These findings are further supported by our previous studies with a transgenic mouse model overexpressing mitochondrial CAT which showed extended longevity [62] and significant protection of radiation-induced neurocoginitve deficits [63]. Further studies are needed to investigate the impaired expression of SOD2 and CAT in the specific neuronal cells of the hippocampus by immunostaining and whether SOD2 knockdown or CAT overexpression can alleviate the post-irradiation loss of cognitive functions in Cebpd ${ }^{-/-}$mice.

Taken together, our results show that Cebpd-deficiency promotes radiation-induced deficits in short-term memory and spatial learning in aged mice that may be due to an impaired ability to detoxify IR-induced oxidative stress.

\section{Materials and Methods}

\subsection{Ethics Statement}

This study was carried out in strict accordance with the recommendations in the Guide for the Care and Use of Laboratory Animals of the National Institutes of Health and approved by the Institutional Animal Care and Use Committee of the University of Arkansas for Medical Sciences, animal use protocol number \#3511, approved on 5/20/2014).

\subsection{Animals}

Cebpd-heterozygous breeder mice were backcrossed for more than 20 generations to the C57BL/ 6 strain background. Genotyping was done as described previously [34]. In all the studies, 15-month-old male Cebpd $d^{+/+}$and Cebpd $d^{-/-}$littermate mice were used. The animals were housed in the Division of Laboratory Medicine (DLAM, University of Arkansas for Medical Sciences, Little Rock, AR, USA) under standardized conditions with controlled temperature and humidity and a 12-h day, 12-h night light cycle. Brain tissues were harvested from sham mice and from irradiated mice at day 11 post-IR following isoflurane inhalation to minimize suffering and the animals were euthanized by cervical dislocation.

\subsection{Irradiation of Mice}

$\mathrm{Cebpd}^{+/+}$and Cebpd ${ }^{-/-}$mice were exposed to TBI administered in a Mark I irradiator (J. L. Shepherd \& Associates, San Fernando, CA, USA). Dose uniformity was assessed by an independent company (Ashland Specialty Ingredients, Wilmington, DE, USA) with radiographic film and alanine 
tablets. Alanine tablets were analyzed by the National Institute of Standards and Technology (Gaithersburg, MD, USA) and demonstrated a dose rate of $1.14 \mathrm{~Gy} / \mathrm{min}$ at $21 \mathrm{~cm}$ from the source. For each experiment, the dose rate was corrected for decay.

The total dose of TBI used in the present study was $8.5 \mathrm{~Gy}$. We have previously reported that 3-month-old Cebpd $d^{+/+}$mice exposed to 8.5 Gy led to $100 \%$ mortality by days $9-13$ post-TBI compared to $\mathrm{Cebpd}^{+/+}$mice, which showed $40 \%$ mortality by days $11-13$ post-TBI [34]. Aged (15 months old) Cebpd ${ }^{-/-}$mice display about $55 \%$ mortality by days $8-12$ compared to $12.5 \%$ mortality at day 15 post-TBI dose of 8.5 Gy (Pawar et al., unpublished results, data not shown). Hence, we chose the timepoint of 7-10 days post-irradiation for the behavior studies followed by tissue harvest on day 11 post-irradiation to examine the morphological changes and molecular changes in the hippocampus.

\subsection{Behavioral Methods}

In the sham group, $n=5$ mice for each genotype, where in the IR group, Cebpd $d^{+/+}$mice $(n=7)$ and Cebpd $d^{-1-}$ mice $(n=5)$ were used for the behavior studies. The figure below depicts the timepoints for the behavior studies that were conducted prior to tissue harvest.

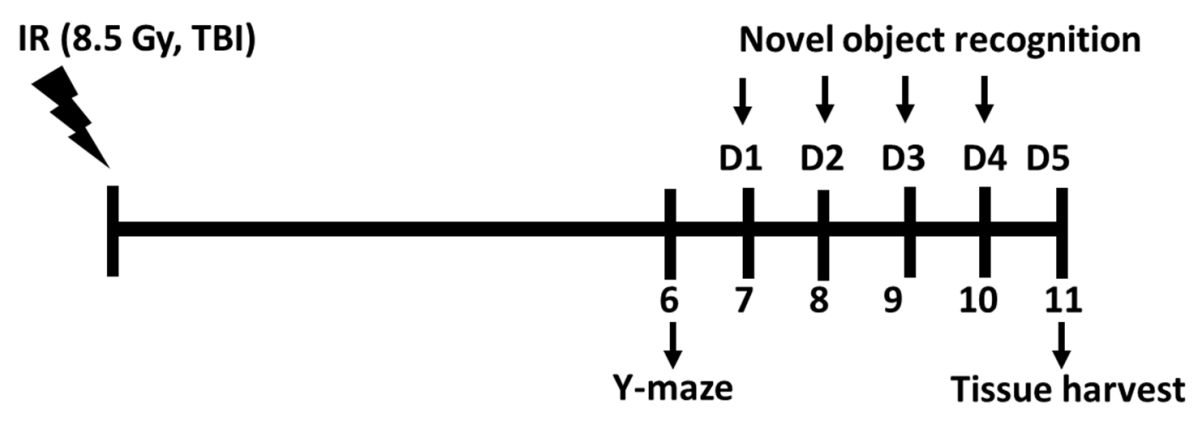

\subsubsection{Y-Maze}

At day 6 post-irradiation, $\mathrm{Cebpd}^{+/+}$and Cebpd $d^{-/-}$mice were first tested in the Y-maze, which did not rely on either negative or positive reinforcement. The maze was constructed out of acrylic and consisted of three similar arms (45L x 7W x $14 \mathrm{H} \mathrm{cm}$ ): a "start" arm where animals were placed initially, a "familiar" arm, and a "novel" arm. The familiar and novel arms each contained an object of different size and shape mounted at the end of the arm. Animals were placed in the start arm facing away from the center of the maze. The familiarization session consisted of free exploration of the start and familiar arms for $10 \mathrm{~min}$. Four hours later, the testing session was held; animals were again placed in the maze, this time with access to all arms. Allocation of arms (start, familiar, or novel) was counterbalanced between each experimental group. Trials lasted for $10 \mathrm{~min}$, and center- and nose-points were recorded throughout each session. An arm entry was counted when all four limbs of the mouse entered an arm. All experimental arenas were wiped clean with $20 \%$ ethanol after each trial. All behavioral experiments were conducted during the light cycle under dimly-lit (white light) conditions, after a minimum of one hour of acclimation. Behavioral experiments were recorded on a charge-coupled device video camera, located above the maze for automatic behavioral analysis with EthoVision XT software version 11 (Noldus Information Technology, Leesburg, VA, USA) as described previously [23].

\subsubsection{Novel Object Recognition}

On day 7 post-irradiation, $\mathrm{Cebpd}^{+/+}$and $\mathrm{Cebpd}^{-/-}$mice were tested for novel object recognition (NOR) with a 4-day procedure in which animals freely explored an arena for $10 \mathrm{~min}$ each day. The arena was a cube consisting of an aluminum floor, acrylic walls $(41 \mathrm{~L} \times 41 \mathrm{~W} \times 35 \mathrm{H} \mathrm{cm})$, and an open ceiling. The first two days (days 7 and 8 post-TBI) served as habituation learning days, in which mice were able to explore the empty arena (effectively serving as open field tests); locomotor activity was measured at this stage. The familiarization phase occurred on day 3 (day 9 post-TBI), when animals explored an 
arena containing two identical objects (cell-culture flasks filled with sand). Novel object recognition testing occurred on day 4 (day 10 post-TBI); here, a now-familiar object was replaced with a novel object (large LEGO $^{\circledR}$ blocks assembled to the size of the cell-culture flasks) [64]. Animals were placed in the center of the arena parallel to the objects to avoid bias. NOR testing relies on the animals' natural inclination to explore novel objects in their environment (untreated animals should spend significantly more time exploring the novel object). The tracking software was programmed to track animal center-points for the habituation trials and nose-points during familiarization and testing trials.

\subsubsection{Golgi Staining}

Shortly after behavioral testing, animals were euthanized, and their brains were collected at day 11 post- 8.5 Gy and dissected along the midsagittal plane and half of the hippocampus was harvested for Golgi staining. The Golgi method of staining has long proven to be a reliable method for assessing dendrite and dendritic spine dynamics due to various treatments, because of its resistance to fading or photobleaching over time $[65,66]$. We adapted a staining protocol and used the reagents contained in the superGolgi kit (Bioenno Tech, Santa Ana, CA, USA) [67]. Right hemispheres were immediately impregnated in a potassium dichromate solution for two weeks $(n=5)$. Next, sections were immersed for at least $48 \mathrm{~h}$ in a post-impregnation buffer. Samples were sectioned at $200 \mu \mathrm{m}$ in $1 \times$ PBS along the coronal plane. Samples were then transferred into wells and washed with $0.01 \mathrm{M}$ PBS buffer (pH 7.4) with Triton X-100 (0.3\%) (PBS-T). Immediately after washing, samples were stained with ammonium hydroxide and then immersed in a post-staining buffer. Sections were again washed in PBS-T, mounted on $1 \%$ gelatin-coated slides, and allowed to dry. Sections were finally dehydrated with ethanol solutions, followed by cleaning in xylene, and coverslipped with Permount ${ }^{\mathrm{TM}}$ (Thermo Fisher Scientific, Waltham, MA, USA).

\subsubsection{Dendritic Morphology Quantification}

All dendritic morphology data were collected blinded with regard to experimental conditions on $n=5$ mice per genotype per treatment group. We performed quantification of morphological characteristics of the granular and pyramidal neurons contained in the hippocampal formation using techniques that included Sholl analyses (Figure S2, Supplementary Materials), total dendritic length, number of branch points, and dendritic complexity index (DCI). Multiple Z-stack images of neurons were collected with the aid of a computer-assisted neuron tracing using the Neuroexplorer component of the Neurolucida program (Ver. 11, Microbrightfield, Inc., Williston, VT, USA). Sholl analysis was used to assess the amount and distribution of the arbor at increasing radial distances from the cell body [68]. Radii were set to extend in $10 \mu \mathrm{m}$ intervals from the soma. The length of each dendritic branch, within each progressively larger circle, was counted from the soma, with respect to three dimensions. This provided information about the amount and distribution of individual dendrites.

We then performed branch-point analyses. Branch points occur at bifurcations of the dendrite when a branch divides into two sub-branches. Branch-point analysis depends on the number of bifurcations and the order of the points [69]. Lower branch-point orders represent proximal regions of the tree, whereas larger branch-point orders characterize distal regions. We used the branch-point analysis to determine the complexity of dendritic arborization, because the complexity of the dendritic tree is an important phenotypic component of branching analysis. DCI was determined by the following equation: $\mathrm{DCI}=\sum$ (branch tip orders $+\#$ of branch tips $) \times($ total dendritic length/total number of primary dendrites). In the CA1 apical and basal regions, dendrites were analyzed separately.

\subsubsection{Immunoblotting of Hippocampal Extracts}

Hippocampal tissues were harvested from sham and irradiated Cebpd ${ }^{+/+}$and Cebpd ${ }^{-/-}$mice at day 11 post-irradiation and protein extracts were prepared using an IBI Scientific DNA/RNA/Protein Extraction kit (MIDSCI, St. Louis, MO, USA), and the protein was quantified using a Nanodrop 2000c A280 (Thermo Scientific, Waltham, MA, USA). The protein samples were mixed with $2 \times$ sodium 
dodecyl sulfate polyacrylamide gel electrophoresis sample buffer and boiled for $5 \mathrm{~min}$. A $35 \mu \mathrm{g}$ portion of total protein per sample was separated by a $4-20 \%$ gradient sodium dodecyl sulfate polyacrylamide gel electrophoresis, electrotransferred to polyvinylidene fluoride (PVDF) filters at $40 \mathrm{~V}$ and $4{ }^{\circ} \mathrm{C}$ for $120 \mathrm{~min}$, blocked with $5 \%$ non-fat milk at room temperature for $1 \mathrm{~h}$, and incubated with primary antibodies specific to NRF2 (sc-722), SOD2 (sc-30080), CAT (sc-50508), $\gamma$-GCSm (sc-55586), TLR4 (sc-293072), and CD68 (sc-59103) (Santa Cruz Biotechnology, Dallas, TX, USA), and $\beta$-actin (4790, Cell Signaling Technology, Danvers, MA, USA) monoclonal antibodies overnight at $4{ }^{\circ} \mathrm{C}$. The membranes were washed three times with Tris-buffered saline/Tween-20 (TBST), incubated with secondary antibody for $60 \mathrm{~min}$, washed three times with TBST, and visualized by enhanced chemiluminiscence. $\beta$-actin expression was used as the internal reference. The band intensities were measured by densitometry using NIH ImageJ analysis.

\subsubsection{Statistical Analyses}

We expressed data as a mean \pm the standard error of the mean (SEM). We analyzed the behavioral data throughout the 10-minute length of each test. Behavioral assays comparing visits or time spent in apparatus areas by individual treatment groups were analyzed via ANOVA. NOR discrimination ratio (DR) was calculated by the following formula: (NOR) DR $=$ (novel object visits - familiar object visits)/(novel object visits + familiar object visits). For measures of dendritic length, two-way repeated-measures ANOVA was conducted for the effects of radiation (between-subjects variable) and distance from the cell soma (Sholl radius, repeated-measures variable); Holm's correction to control for multiple comparisons post-hoc tests followed, when appropriate. Densitometry data were analyzed by unpaired Student's $t$-test. All statistical analyses were conducted with GraphPad Prism 7.0 software (La Jolla, CA, USA) in a 95\% confidence interval, and $p<0.05$ was considered significant.

Supplementary Materials: The following are available online at http:/ /www.mdpi.com/1422-0067/20/4/885/s1, Figure S1: Discrimination ratio of sham and irradiated aged Cebpd $d^{+/+}$and Cebpd $d^{-/}$mice. Figure S2: Combined Sholl analyses of neurons in DG and CA1 apical and CA1 basal regions depicted in Figures 3-5. Figure S3: Representative tracings of DG granule neurons superimposed over concentric rings $(10 \mu \mathrm{M})$ used for Sholl analysis.

Author Contributions: A.R.A. and S.A.P. conceived, designed and directed the experiments; S.B., T.A., D.M., T.G., F.K., J.W., and A.G. performed the experiments; J.W. and A.R.A. analyzed the data; A.R.A. and S.A.P. contributed reagents, materials, and analysis tools; S.B., S.A.P., and A.R.A. wrote the paper.

Funding: This research was funded by National Institute of General Medical Sciences supported COBRE-Center for Host Responses to Cancer Therapy Grant P20GM109005 (ARA, SAP); Department of Defense Congressionally Directed Medical Research Program Award W81XWH-15-1-0489 (SAP), and the Arkansas Bioscience Institute (SAP). The authors also wish to acknowledge the support provided by the core facilities of the National Institute of General Medical Sciences supported Center for Translational Neuroscience (P30 GM110702).

Acknowledgments: The authors would like to thank Esta Sterneck (National Cancer Institute, Frederick, MD, USA) for kindly providing us the Cebpd heterozygous mice to generate the experimental animals. The authors acknowledge Randolph Mildred, Gail Wagoner, Bianca Schutte, Rebecca Mitchell, Jeannie Holland and Bridgette Angie from the Division of Laboratory Animals and Medicine for excellent animal care.

Conflicts of Interest: The authors declare no conflict of interest. The funding sponsors had no role in the design of the study; in the collection, analyses, or interpretation of data; in the writing of the manuscript; and in the decision to publish the results.

\section{References}

1. Hladik, D.; Tapio, S. Effects of ionizing radiation on the mammalian brain. Mutat. Res. Rev. Mutat. Res. 2016, 770, 219-230. [CrossRef] [PubMed]

2. Hernandez, L.; Terradas, M.; Camps, J.; Martin, M.; Tusell, L.; Genesca, A. Aging and radiation: Bad companions. Aging Cell 2015, 14, 153-161. [CrossRef] [PubMed]

3. Monje, M.L.; Toda, H.; Palmer, T.D. Inflammatory blockade restores adult hippocampal neurogenesis. Science 2003, 302, 1760-1765. [CrossRef] [PubMed]

4. Voloboueva, L.A.; Giffard, R.G. Inflammation, mitochondria, and the inhibition of adult neurogenesis. J. Neurosci. Res. 2011, 89, 1989-1996. [CrossRef] [PubMed] 
5. Huang, T.-T.; Leu, D.; Zou, Y. Oxidative stress and redox regulation on hippocampal-dependent cognitive functions. Arch. Biochem. Biophys. 2015, 576, 2-7. [CrossRef] [PubMed]

6. Betlazar, C.; Middleton, R.J.; Banati, R.B.; Liu, G.-J. The impact of high and low dose ionising radiation on the central nervous system. Redox Biol. 2016, 9, 144-156. [CrossRef]

7. Lumniczky, K.; Szatmári, T.; Sáfrány, G. Ionizing Radiation-Induced Immune and Inflammatory Reactions in the Brain. Front. Immunol. 2017, 8, 517. [CrossRef]

8. Roman, D.D.; Sperduto, P.W. Neuropsychological effects of cranial radiation: Current knowledge and future directions. Int. J. Radiat. Oncol. Biol. Phys. 1995, 31, 983-998. [CrossRef]

9. Fike, J.R.; Gobbel, G.T. Central nervous system radiation injury in large animal models. In Radiation Injury to the Nervous System; Gutin, P.H., Leibel, S.A., Sheline, G.E., Eds.; Raven Press, Ltd.: New York, NY, USA, 1991; pp. 113-135.

10. Tofilon, P.J.; Fike, J.R. The radioresponse of the central nervous system: A dynamic process. Radiat. Res. 2000, 153, 357-370, Epub 2000/05/08. [CrossRef]

11. Abayomi, O.K. Pathogenesis of irradiation-induced cognitive dysfunction. Acta Oncol. 1996, 35, $659-663$. [CrossRef]

12. Son, Y.; Yang, M.; Wang, H.; Moon, C. Hippocampal dysfunctions caused by cranial irradiation: A review of the experimental evidence. Brain Behav. Immun. 2015, 45, 287-296. [CrossRef] [PubMed]

13. Greene-Schloesser, D.; Moore, E.; Robbins, M.E. Molecular Pathways: Radiation-Induced Cognitive Impairment. Clin. Cancer Res. 2013, 19, 2294-2300. [CrossRef] [PubMed]

14. Broadbent, N.J.; Squire, L.R.; Clark, R.E. Spatial memory, recognition memory, and the hippocampus. Proc. Natl. Acad. Sci. USA 2004, 101, 14515-14520. [CrossRef] [PubMed]

15. Casciati, A.; Dobos, K.; Antonelli, F.; Benedek, A.; Kempf, S.J.; Bellés, M.; Balogh, A.; Tanori, M.; Heredia, L.; Atkinson, M.J.; et al. Age-related effects of X-ray irradiation on mouse hippocampus. Oncotarget 2016, 7, 28040-28058. [CrossRef] [PubMed]

16. Beckervordersandforth, R.; Ebert, B.; Schäffner, I.; Moss, J.; Fiebig, C.; Shin, J.; Moore, D.L.; Ghosh, L.; Trinchero, M.F.; Stockburger, C.; et al. Role of Mitochondrial Metabolism in the Control of Early Lineage Progression and Aging Phenotypes in Adult Hippocampal Neurogenesis. Neuron 2017, 93, 560.e6-573.e6. [CrossRef]

17. Knobloch, M.; Jessberger, S. Metabolism and neurogenesis. Curr. Opin. Neurobiol. 2017, 42, 45-52. [CrossRef]

18. Wu, P.H.; Coultrap, S.; Pinnix, C.; Davies, K.D.; Tailor, R.; Ang, K.K.; Browning, M.D.; Grosshans, D.R. Radiation induces acute alterations in neuronal function. PLoS ONE 2012, 7, e37677. [CrossRef]

19. Kumar, M.; Haridas, S.; Trivedi, R.; Khushu, S.; Manda, K. Early cognitive changes due to whole body gamma-irradiation: A behavioral and diffusion tensor imaging study in mice. Exp. Neurol. 2013, 248, 360-368. [CrossRef]

20. Chakraborti, A.; Allen, A.; Allen, B.; Rosi, S.; Fike, J.R. Cranial Irradiation Alters Dendritic Spine Density and Morphology in the Hippocampus. PLoS ONE 2012, 7, e40844. [CrossRef]

21. Parihar, V.K.; Limoli, C.L. Cranial irradiation compromises neuronal architecture in the hippocampus. Proc. Natl. Acad. Sci. USA 2013, 110, 12822-12827. [CrossRef]

22. Parihar, V.K.; Pasha, J.; Tran, K.K.; Craver, B.M.; Acharya, M.M.; Limoli, C.L. Persistent changes in neuronal structure and synaptic plasticity caused by proton irradiation. Brain Struct. Funct. 2015, 220, 1161-1171. [CrossRef]

23. Kiffer, F.; Howe, A.K.; Carr, H.; Wang, J.; Alexander, T.; Anderson, J.E.; Groves, T.; Seawright, J.W.; Sridharan, V.; Carter, G.; et al. Late effects of (1)H irradiation on hippocampal physiology. Life Sci. Space Res. 2018, 17, 51-62. [CrossRef] [PubMed]

24. Shuryak, I.; Sachs, R.K.; Brenner, D.J. Cancer risks after radiation exposure in middle age. J. Natl. Cancer Inst. 2010, 102, 1628-1636. [CrossRef] [PubMed]

25. Ramji, D.P.; Foka, P. CCAAT/enhancer-binding proteins: Structure, function and regulation. Biochem. J. 2002, 365, 561-575. [CrossRef] [PubMed]

26. Sarkar, T.R.; Sharan, S.; Wang, J.; Pawar, S.A.; Cantwell, C.A.; Johnson, P.F.; Morrison, D.K.; Wang, J.M.; Sterneck, E. Identification of a Src tyrosine kinase/SIAH2 E3 ubiquitin ligase pathway that regulates C/EBPdelta expression and contributes to transformation of breast tumor cells. Mol. Cell Biol. 2012, 32, 320-332. [CrossRef] 
27. Pawar, S.A.; Sarkar, T.R.; Balamurugan, K.; Sharan, S.; Wang, J.; Zhang, Y.; Dowdy, S.F.; Huang, A.M.; Sterneck, E. C/EBP delta targets cyclin D1 for proteasome-mediated degradation via induction of CDC27/APC3 expression. Proc. Natl. Acad. Sci. USA 2010, 107, 9210-9215. [CrossRef] [PubMed]

28. Thangaraju, M.; Rudelius, M.; Bierie, B.; Raffeld, M.; Sharan, S.; Hennighausen, L.; Huang, A.M.; Sterneck, E. $\mathrm{C} / \mathrm{EBPdelta}$ is a crucial regulator of pro-apoptotic gene expression during mammary gland involution. Development 2005, 132, 4675-4685. [CrossRef]

29. Huang, A.M.; Montagna, C.; Sharan, S.; Ni, Y.; Ried, T.; Sterneck, E. Loss of CCAAT/enhancer binding protein delta promotes chromosomal instability. Oncogene 2004, 23, 1549-1557. [CrossRef]

30. Hour, T.C.; Lai, Y.L.; Kuan, C.I.; Chou, C.K.; Wang, J.M.; Tu, H.Y.; Hu, H.T.; Lin, C.S.; Wu, W.J.; Pu, Y.S.; et al. Transcriptional up-regulation of SOD1 by CEBPD: A potential target for cisplatin resistant human urothelial carcinoma cells. Biochem. Pharmacol. 2010, 80, 325-334. [CrossRef]

31. Wang, J.; Sarkar, T.R.; Zhou, M.; Sharan, S.; Ritt, D.A.; Veenstra, T.D.; Morrison, D.K.; Huang, A.M.; Sterneck, E. CCAAT/enhancer binding protein delta (C/EBPdelta, CEBPD)-mediated nuclear import of FANCD2 by IPO4 augments cellular response to DNA damage. Proc. Natl. Acad. Sci. USA 2010, 107, 16131-16136. [CrossRef]

32. Cardinaux, J.R.; Allaman, I.; Magistretti, P.J. Pro-inflammatory cytokines induce the transcription factors C/EBPbeta and C/EBPdelta in astrocytes. Glia 2000, 29, 91-97. [CrossRef]

33. Li, R.; Strohmeyer, R.; Liang, Z.; Lue, L.F.; Rogers, J. CCAAT/enhancer binding protein delta (C/EBPdelta) expression and elevation in Alzheimer's disease. Neurobiol. Aging 2004, 25, 991-999. [CrossRef] [PubMed]

34. Pawar, S.A.; Shao, L.; Chang, J.; Wang, W.; Pathak, R.; Zhu, X.; Wang, J.; Hendrickson, H.; Boerma, M.; Sterneck, E.; et al. C/EBP delta Deficiency Sensitizes Mice to Ionizing Radiation-Induced Hematopoietic and Intestinal Injury. PLoS ONE 2014, 9, e94967. [CrossRef]

35. Banerjee, S.; Aykin-Burns, N.; Krager, K.J.; Shah, S.K.; Melnyk, S.B.; Hauer-Jensen, M.; Pawar, S.A. Loss

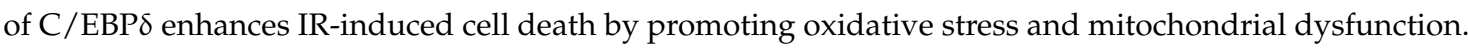
Free Radic. Biol. Med. 2016, 99, 296-307. [CrossRef]

36. Dellu, F.; Fauchey, V.; Le Moal, M.; Simon, H. Extension of a new two-trial memory task in the rat: Influence of environmental context on recognition processes. Neurobiol. Learn. Mem. 1997, 67, 112-120. [CrossRef]

37. Ran, Y.; Yan, B.; Li, Z.; Ding, Y.; Shi, Y.; Le, G. Dityrosine administration induces novel object recognition deficits in young adulthood mice. Physiol. Behav. 2016, 164, 292-299. [CrossRef]

38. Cohen, S.J.; Stackman, R.W., Jr. Assessing rodent hippocampal involvement in the novel object recognition task. A review. Behav. Brain Res. 2015, 285, 105-117. [CrossRef] [PubMed]

39. Burke, S.N.; Wallace, J.L.; Nematollahi, S.; Uprety, A.R.; Barnes, C.A. Pattern separation deficits may contribute to age-associated recognition impairments. Behav. Neurosci. 2010, 124, 559-573. [CrossRef] [PubMed]

40. Hofer, T.; Duale, N.; Muusse, M.; Eide, D.M.; Dahl, H.; Boix, F.; Andersen, J.M.; Olsen, A.K.; Myhre, O. Restoration of Cognitive Performance in Mice Carrying a Deficient Allele of 8-Oxoguanine DNA Glycosylase by X-ray Irradiation. Neurotox. Res. 2018, 33, 824-836. [CrossRef] [PubMed]

41. Mizumatsu, S.; Monje, M.L.; Morhardt, D.R.; Rola, R.; Palmer, T.D.; Fike, J.R. Extreme sensitivity of adult neurogenesis to low doses of X-irradiation. Cancer Res. 2003, 63, 4021-4027. [PubMed]

42. Romanko, M.J.; Rola, R.; Fike, J.R.; Szele, F.G.; Dizon, M.L.; Felling, R.J.; Brazel, C.Y.; Levison, S.W. Roles of the mammalian subventricular zone in cell replacement after brain injury. Prog. Neurobiol. 2004, 74, 77-99. [CrossRef] [PubMed]

43. Sterneck, E.; Paylor, R.; Jackson-Lewis, V.; Libbey, M.; Przedborski, S.; Tessarollo, L.; Crawley, J.N.; Johnson, P.F. Selectively enhanced contextual fear conditioning in mice lacking the transcriptional regulator CCAAT/enhancer binding protein delta. Proc. Natl. Acad. Sci. USA 1998, 95, 10908-10913. [CrossRef] [PubMed]

44. Sharman, E.H.; Bondy, S.C.; Sharman, K.G.; Lahiri, D.; Cotman, C.W.; Perreau, V.M. Effects of melatonin and age on gene expression in mouse CNS using microarray analysis. Neurochem. Int. 2007, 50, 336-344. [CrossRef] [PubMed]

45. Sarnyai, Z.; Sibille, E.L.; Pavlides, C.; Fenster, R.J.; McEwen, B.S.; Toth, M. Impaired hippocampal-dependent learning and functional abnormalities in the hippocampus in mice lacking serotonin(1A) receptors. Proc. Natl. Acad. Sci. USA 2000, 97, 14731-14736. [CrossRef] [PubMed] 
46. Gruber, M.J.; Gelman, B.D.; Ranganath, C. States of curiosity modulate hippocampus-dependent learning via the dopaminergic circuit. Neuron 2014, 84, 486-496. [CrossRef]

47. Kiffer, F.; Alexander, T.; Anderson, J.E.; Groves, T.; Wang, J.; Sridharan, V.; Boerma, M.; Allen, A.R. Late Effects of (16)O-Particle Radiation on Female Social and Cognitive Behavior and Hippocampal Physiology. Radiat. Res. 2019. [CrossRef] [PubMed]

48. Larkin, M.C.; Lykken, C.; Tye, L.D.; Wickelgren, J.G.; Frank, L.M. Hippocampal output area CA1 broadcasts a generalized novelty signal during an object-place recognition task. Hippocampus 2014, 24, 773-783. [CrossRef] [PubMed]

49. Stepan, J.; Dine, J.; Eder, M. Functional optical probing of the hippocampal trisynaptic circuit in vitro: Network dynamics, filter properties, and polysynaptic induction of CA1 LTP. Front. Neurosci. 2015, 9, 160. [CrossRef] [PubMed]

50. Kulkarni, V.A.; Firestein, B.L. The dendritic tree and brain disorders. Mol. Cell. Neurosci. 2012, 50, 10-20. [CrossRef] [PubMed]

51. Nimchinsky, E.A.; Sabatini, B.L.; Svoboda, K. Structure and function of dendritic spines. Annu. Rev. Physiol. 2002, 64, 313-353. [CrossRef] [PubMed]

52. Segal, M. Dendritic spines and long-term plasticity. Nat. Rev. Neurosci. 2005, 6, 277-284. [CrossRef] [PubMed]

53. Yuste, R.; Bonhoeffer, T. Morphological changes in dendritic spines associated with long-term synaptic plasticity. Annu. Rev. Neurosci. 2001, 24, 1071-1089. [CrossRef] [PubMed]

54. Raber, J.; Allen, A.R.; Sharma, S.; Allen, B.; Rosi, S.; Olsen, R.H.; Davis, M.J.; Eiwaz, M.; Fike, J.R.; Nelson, G.A. Effects of Proton and Combined Proton and (56)Fe Radiation on the Hippocampus. Radiat. Res. 2016, 185, 20-30. [CrossRef] [PubMed]

55. Sydow, A.; Hochgrafe, K.; Konen, S.; Cadinu, D.; Matenia, D.; Petrova, O.; Joseph, M.; Dennissen, F.J.; Mandelkow, E.M. Age-dependent neuroinflammation and cognitive decline in a novel Ala152Thr-Tau transgenic mouse model of PSP and AD. Acta Neuropathol. Commun. 2016, 4, 17. [CrossRef] [PubMed]

56. Richardson, R.B. Ionizing radiation and aging: Rejuvenating an old idea. Aging 2009, 1, 887-902. [CrossRef]

57. Glass, C.K.; Saijo, K.; Winner, B.; Marchetto, M.C.; Gage, F.H. Mechanisms underlying inflammation in neurodegeneration. Cell 2010, 140, 918-934. [CrossRef]

58. Wilhelm, I.; Nyul-Toth, A.; Kozma, M.; Farkas, A.E.; Krizbai, I.A. Role of pattern recognition receptors of the neurovascular unit in inflamm-aging. Am. J. Physiol. Heart Circ. Physiol. 2017, 313, H1000-H1012. [CrossRef]

59. Banerjee, S.F.Q.; Shah, S.K.; Ponnappan, U.; Melnyk, S.B.; Hauer-Jensen, N.; Pawar, S.A. Role of TLR4 in the pathogenesis of radiation-induced intestinal injury in C/EBP $\delta$-knockout mice. In SHOCK; Lippincott Williams \& Wilkins: Fort Lauderdale, FL, USA, 2017.

60. Robello, E.; Bonetto, J.G.; Puntarulo, S. Cellular Oxidative/Antioxidant Balance in gamma-Irradiated Brain: An Update. Mini-Rev. Med. Chem. 2016, 16, 937-946. [CrossRef]

61. Fishman, K.; Baure, J.; Zou, Y.; Huang, T.-T.; Andres-Mach, M.; Rola, R.; Suarez, T.; Acharya, M.; Limoli, C.L.; Lamborn, K.R.; et al. Radiation-induced reductions in neurogenesis are ameliorated in mice deficient in CuZnSOD or MnSOD. Free Radic. Biol. Med. 2009, 47, 1459-1467. [CrossRef]

62. Dai, D.F.; Chiao, Y.A.; Martin, G.M.; Marcinek, D.J.; Basisty, N.; Quarles, E.K.; Rabinovitch, P.S. Mitochondrial-Targeted Catalase: Extended Longevity and the Roles in Various Disease Models. Prog. Mol. Biol. Transl. Sci. 2017, 146, 203-241.

63. Parihar, V.K.; Allen, B.D.; Tran, K.K.; Chmielewski, N.N.; Craver, B.M.; Martirosian, V.; Morganti, J.M.; Rosi, S.; Vlkolinsky, R.; Acharya, M.M.; et al. Targeted overexpression of mitochondrial catalase prevents radiation-induced cognitive dysfunction. Antioxid. Redox Signal. 2015, 22, 78-91. [CrossRef]

64. Leger, M.; Quiedeville, A.; Bouet, V.; Haelewyn, B.; Boulouard, M.; Schumann-Bard, P.; Freret, T. Object recognition test in mice. Nat. Protoc. 2013, 8, 2531-2537. [CrossRef] [PubMed]

65. Zhao, Z.H.; Zheng, G.; Wang, T.; Du, K.J.; Han, X.; Luo, W.J.; Shen, X.F.; Chen, J.Y. Low-level Gestational Lead Exposure Alters Dendritic Spine Plasticity in the Hippocampus and Reduces Learning and Memory in Rats. Sci. Rep. 2018, 8, 3533. [CrossRef] [PubMed]

66. Mikolaenko, I.; Rao, L.M.; Roberts, R.C.; Kolb, B.; Jinnah, H.A. A Golgi study of neuronal architecture in a genetic mouse model for Lesch-Nyhan disease. Neurobiol. Dis. 2005, 20, 479-490. [CrossRef] [PubMed]

67. Groves, T.R.; Wang, J.; Boerma, M.; Allen, A.R. Assessment of Hippocampal Dendritic Complexity in Aged Mice Using the Golgi-Cox Method. J. Vis. Exp. JoVE 2017. [CrossRef] [PubMed] 
68. Sholl, D.A. Dendritic organization in the neurons of the visual and motor cortices of the cat. J. Anat. 1953, 87, 387-406. [PubMed]

69. Morley, B.J.; Mervis, R.F. Dendritic spine alterations in the hippocampus and parietal cortex of alpha7 nicotinic acetylcholine receptor knockout mice. Neuroscience 2013, 233, 54-63. [CrossRef] [PubMed] 